Whale Stocks and Whaling Norsk Hvalfangst-Tidende, now in its thirty-fourth year, is the
official organ of the Norwegian Whaling Association. It is a current history of whaling and publishes information on all branches of the subject.

I have begun to receive it again and would refer to an article in the August number (p. 117) entitled "Shipping, Whaling and the Supply of Fats". In it, Shipbuilding and Shipping Record of August 23, 1945 , is stated to have printed a report on post-war policy from the Whaler Section of the Chamber of Shipping of the United Kingdom which had been presented to the Ministries of Food, Agriculture and War Transport, and contained the following statement: "The unique advantage of whaling as a major source of food production to meet the urgent needs of the post-war period lies in the fact that the stock the urgent needs of the post-war period lies in the fact that the stock
of whales has increased considerably in the years since 1939-40, during which practically no whaling operations have been carried out", and goes on at length with discussion of outflting factories.

and goes on at length with discussion of outflting factories.
The editorial comment (p. 119) referring to this passage states that, "What is said about the considerable increase of the stock of whales "What is said about the considerable increase of the stock of whales we fear is a too optimistic view. One must take into consideration that the taxation of the whale stocks during the last three seasons
before the war was very heavy. . . In spite of the big increase in before the war was very heavy. . In spite of the big increase in
the number of expeditions and catcher boats the total production the number of expeditions and catcher boats the total production decreased very considerably in the last season, namely, from $3,340,300$
barrels in $1937 / 38$ to $2,820,771$ barrels in $1938 / 39$. . This was a barrels in $1937 / 38$ to $2,820,771$ barrels in $1938 / 39$.
very grave danger signal, and it was obvious that it was a very grave danger signal, and it was obvious that it was the result of a taxation of the whale stocks far too high. ... That it would take time before the wounds were healed again was very likely, and although the whale stocks in Antarctic waters have enjoyed a good holiday during the wartime, reports from the catching field prove that no considerable increase has taken place. . . The manager
of the floating factory 'Sir James Clark Ross' which operated in the Antarctic season $1944 / 45$ says that in his opinion he could not say that there were more whales now than before the war, but that the whales were not so shy as they had been."

The editorial comment ends with correction of the figures for average world production of oil and number of expeditions working for six years to $1939-40$.

I do not propose to offer comment on the disagreement between the journals, but I feel that it should be more widely known.

While considering the future of whaling, I would point out that the present minimum killable lengths set forth in the International Agreement on Whaling are less than the lengths at which whales become sexually mature and are therefore of little or no use for preserving the stock.

It is certain they ought to be revised, and the whalers themselves should consider the matter in their own interests.

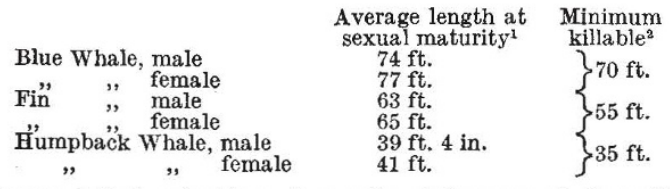

I suggest that, valuable as it may be at the moment, it would be unwise to regard whales as a permanent source of great quantities of meat and oil.

Having regard to the history of all whaling in the past, it seems reasonably probable that the supplies are likely to diminish with perceptible rapidity, even if the results of the flrst season are highly perceptible rapidity, even if the results of the flrst
satisfactory from the point of view of the whalers. Stanley,

Falkland Islands.

Dec. 14.

1. Mackintosh, N. A., Discovery Reps., 22, 217-219 (Cambridge, 1942).

International Agreement for the Regulation of Whaling. Cmd. 5487. Pp. 2 (London: H.M. Stationery Office, 1937.)

\section{Mixed lodophile Populations of the Human Colon and Crecum}

SINCE attention was first directed to the subject by Henneberg ${ }^{1}$, the role of iodophile micro-organisms in the decomposition of starch, cellulose, and other carbohydrates, taking place in the gut diverticula of herbivores, has been repeatedly confirmed ${ }^{3}$. The biochemical and microbiological investigations of Pearson and $\mathrm{Smith}^{3}$, and Smith and Baker ${ }^{4}$, have also shown that in the ox such micro-organisms may afford a major contribution to the synthesis of protein from nonprotein nitrogen occurring in the rumen.

In view of these facts and of the results of recent researches upon In view of these facts and of the results of recent researches upon
the microbial synthesis of vitamins in the gut $t^{5-10}$, the demonstration the microbial synthesis of vitamins in the gut g $^{5-10}$, the demonstration
in the human colon and cæcum of an abundant iodophile population similar to that of herbivores acquires significance. The material used was collected from colostomy and other cases, and was formalized was collected from colostomy and other cases, and was formalized
immediately. Direct microscopical examination of the material, immediately. Direct microscopical examination of the material, disclosed iodophile bacteria in large numbers in the interior and upon disclosed iodophile bacteria in large numbers in the interior and upon the surfaces of plant structures. A speciflc relation to the decomposition
of the vegetable material was indicated by the absence of microorganisms from the surfaces of intact or partially digested muscleflbres also present in the ingesta. The iodophile types included giant clostridia, giant diplococci, slender vibrios, small rods and cocci. Preliminary observations made under the polarizing microscope
suggest that some of these iodophile organisms are able, as in herbivores, suggest that some of these iodophile organisms are able, as in herbivores, to attack true cellulose.

This fact, if confirmed, must acquire interest in connexion with the assertion, which has been repeatedly made $13-15$, that in certain normally low, may be markedly augmented. That any intrinsic beneflt can thereby ensue is altogether questionable. Indeed, an adverse influence has been associated with the condition ${ }^{16}$, owing to the constipation and dyschezia which may result from an' abnormal reduction in the bulk of the fæces. The possibility, however, of a positive or negative relation between such changes in the relative density of the normal microbial population of the colon and cæcum, and the ability or failure to synthesize particular vitamins, cannot be ignored. Further investigations upon the capacity of the iodophile in progress in this laboratory.

FRANK BAKER.

County Technical College, SUSAN PALMER. Nov. 14 .

${ }^{1}$ Henneberg, W., Z. Bl. Baht., ii, 55, 242 (1922).

${ }^{2}$ Baker, F., Nature, 150, 479 (1942).

3 Pearson, R. M., and Smith, J. A. B., Biochem. J., 37, 153 (1943).

Smith, J. A. B., and Baker, F., Biochem. J., 38, 496 (1944).

"Kon, S. K., Biochem. J., 21, 834 (1927).

7 Najjar, V. A., and Hoit, L. E., jun., J. Amer. Med. A880c., 123, 683 (1943).

Nielsen, E., and Black, A., Proc. Soc. Exp. Biol., New York, 55,

west, H. D., Jefferson, N. C., and Rivera, R. E., J. Nutr., 25, 471 (1943).

${ }^{10}$ Ellinger, P., and Benesch, R., Lancet, 432 (April 1945).

12 Baker, F., and Martin, R., Z. Bl. Bakt., ii, 97, 201 (1937).

12 Baker, F., Ann. Appl. Biol., 30, 230 (1943).

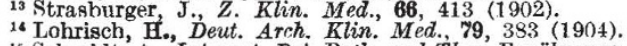

${ }_{15}$ Schmidt, A., Internat. Bei. Path. und Ther. Ernährungs., 3, 1 (1912)

Hurst, A. F., "Constipation and Allied Intestinal Disorders"

(London, 1919).

Hatching of the Egg of Ixodes ricinus L.

DURING the course of an ecological investigation, we have had abundant opportunity for observing eggs of Ixodes ricinus L. A recent communication $^{1}$ on the mechanism of the hatching process raises som points of interest.

Reference is made to the appearance, in eggs maintained at $60^{\circ} \mathrm{F}$ and 80 per cent relative humidity, of an extensive white dumb-bell shaped area, which is evident between twenty-one and thirty days after oviposition. Mr. Arthur does not indicate whether this was observed in living eggs or in preserved material, and consequently, it is difficult to decide to what structure the description refers. We assume the area in question to be the sac formed at the junction of the Malpighian tubules with the gut, which when distended with excretory material becomes a distinct white structure readily visible in living eggs. If this incerpretation be correct, we would suggest that the time limits stated, for the given temperature conditions, are much shorter than in our observations. Although the species exhibits a wide. degree of variation in all its developmenta consider that thirty-five to forty days would be a minimum for the consider that thirty-five to forty days
appearance of this structure at $60^{\circ} \mathrm{F}$.

Mr. Arthur describes a reflexion of the larval head for a period of Mr. Arthur describes a reflexion of the larval head for a period of
7-10 days after hatching. We have never observed this condition $7-10$ days after hatching. We have never observed this condition
in healthy larvæ at any time subsequent to emergence, where they in healthy larvæ at any time subsequent to emergence, where they
have been reared at temperatures between $14^{\circ}$ and $22^{\circ} \mathrm{C}$., and at or have been reared at temperatures between $14^{\circ}$ and $22^{\circ} \mathrm{C}$., and at or near saturation vapour pressure. The mouthparts of newly emerged larvæ are directed forwards, and may be depressed ventrally at an approximate angle of $30^{\circ}$ to the longitudinal axis ; and a slight ventral depression frequently persists in mature larvæ. When eggs are subjected to unfavourable conditions, for example, above $25^{\circ} \mathrm{C}$., a typical abnormality encountered in those individuals which survive and hatch is a persistence of the embryonic dorso-ventral curvature of
the whole length of the body. In these cases the mouthparts are the whole length of the body. In these cases the mouthparts are
not visible from the dorsal aspect. In our experience, 80 per cent not visible from the dorsal aspect. In our experience, 80 per cent
relative humidity is a condition at which a considerable mortality relative humidity is a condition at which a considerable mortality be an abnormality associated with this extreme environmental factor. At the time of hatching, the excretory sac is charged with waste produrts, and the newly emerged larva continues to discharge the contents over a period of several days until the sac is completely emptied. Elimination of excretory products usually begins at th time of hatching, and frequently a quantity of the waste material remains in the eggshell. After emergence, the gut exhibits a welldeflned series of changes, simultaneously with the processes of excretion, and hardening of the chitinous integument. In the newly emerged larva, the gut frequently appears as a simple sac charged digested, and the gut assumes its typical lobed aspect.

Department of Agricultural and Forest Zoology J. ALLAN CAMPBELI.

$$
\begin{aligned}
& \text { University of Edinburgh. } \\
& \text { Nov. } 22 \text {. }
\end{aligned}
$$

${ }^{1}$ Arthur, D. R., Nature, 156, 538 (1945).

\section{Repetitive Discharge of Giant Nerve Fibres of the Earthworm}

IN experiments on the electrical stimulation of the nerve cord of the earthworm, we have obtained a repetitive discharge of the dorsal giant flbres on stimulation of the isolated intact cord by a constant direct current. So far as we are aware, this has not been described
previously in the earthworm. There is no mention of it in the four papers known to us dealing with the electrical activity of the dorsal giant fibres ${ }^{1-4}$ of this annelid. 